\title{
ANALISIS KEUNGGULAN KOMPARATIF DAN FAKTOR YANG MEMPENGARUHI KINERJA KOPERASI DI PULAU JAWA
}

\author{
Andrian Tri Sasongko ${ }^{1}$, Yeti Lis Purnamadewi ${ }^{2}$, Sri Mulatsih ${ }^{2}$ \\ ${ }^{1}$ Kemeterian Koperasi dan Usaha Kecil dan Menengah \\ ${ }^{2}$ Staff Pengajar FEM IPB
}

\begin{abstract}
Development of cooperatives is an important element that must be done in order to realize the national economic development because the cooperative able to accommodate the community in achieving the goal of improving the welfare of the people based on the principle of mutual cooperation. Differences in regional characteristics lead to diversity in the development and development of cooperatives. Java Island with rapid economic growth, able to build cooperatives in large numbers but the performance of cooperatives and growth is still fluctuating. Therefore, this study aims to determine the comparative advantage in cooperative development and analyze the factors that affect the performance of cooperatives in Java. This research uses secondary data with Method of Econometrika Data Panel and Method of Economic Performance Index of Regional Cooperation (PEKR Index). The results showed that the provinces of Central Java and Yogyakarta have a comparative advantage in the economic development of cooperatives in 2011-2015. Factors affecting the performance of the cooperative is the number of active cooperatives, the number of cooperative employees, own capital cooperatives and PDRB.
\end{abstract}

Keywords: Comparative advantage, Cooperative, Performance, Panel data

\section{PENDAHULUAN}

\section{Latar Belakang}

Koperasi dianggap sebagai suatu bentuk badan usaha yang paling sesuai di Indonesia, hal tersebut didasarkan pada Undang-Undang Dasar 1945 Pasal 33 Ayat 1 yaitu perekonomian disusun sebagai usaha bersama berdasarkan atas azas kekeluargaan. Kondisi ini sesuai dengan prinsip dan jatidiri koperasi yang berorientasi pada sistem kerakyatan. Pengembangan koperasi merupakan salah satu unsur penting dalam proses pembangunan nasional karena koperasi dianggap mampu mewadahi masyarakat mencapai citacita untuk meningkatkan kesejahteraan rakyat berdasarkan kultur kerja sama.
Oleh karena itu pembangunan ekonomi koperasi menjadi bagian yang tidak bisa dipisahkan dari pembangunan ekonomi regional dan nasional.

Berdasarkan data statistik dari Kementerian Koperasi dan UKM, pertumbuhan jumlah koperasi di Indonesia terpusat di Pulau Jawa. Pada tahun 2015 persentase jumlah koperasi di Pulau Jawa mencapai 48,08\%, Sumatera 22,84\%, Sulawesi 10,92\%, Kalimantan 7,82\%, Bali dan Nusa Tenggara 5,97\%, kemudian Maluku dan Papua memiliki persentase jumlah koperasi terkecil yaitu 4,36\%. Laju pertumbuhan jumlah koperasi di Pulau Jawa dalam 5 tahun terakhir cenderung berfluktuatif yaitu 7,48\% (2011), 3,87\% (2012), $-0,37 \%$ (2013), 4,54\% (2014), 
dan $1,02 \%$ (2015) dengan rata-rata sebesar 3,31\%.

Berdasarkan data dari Badan Pusat Statistik, dalam kurun waktu tahun 2011-2015 laju pertumbuhan ekonomi ADHK tahun 2010 di Pulau Jawa cenderung mengalami penurunan tiap tahunnya dengan rata-rata 5,96\%. Namun rata-rata laju pertumbuhan ekonomi di Pulau Jawa tetap berada di atas rata-rata laju pertumbuhan ekonomi Indonesia yaitu 5,64\%.

Beberapa program Kementerian Koperasi dan UKM dalam rangka pengembangan, pemberdayaan dan peningkatan daya saing koperasi antara lain:

1. Peningkatan kualitas SDM melalui diklat dan pendampingan;

2. Peningkatan kapasitas dan perlindungan usaha melalui kebijakan dan insentif;

3. Peningkatan akses pembiayaan dan perluasan skema pembiayaan melalui bantuan permodalan dan kredit lunak;

4. Penguatan kelembagaan usaha melalui moderinisasi usaha;

5. Peningkatan nilai tambah produk dan jangkauan pemasaran.

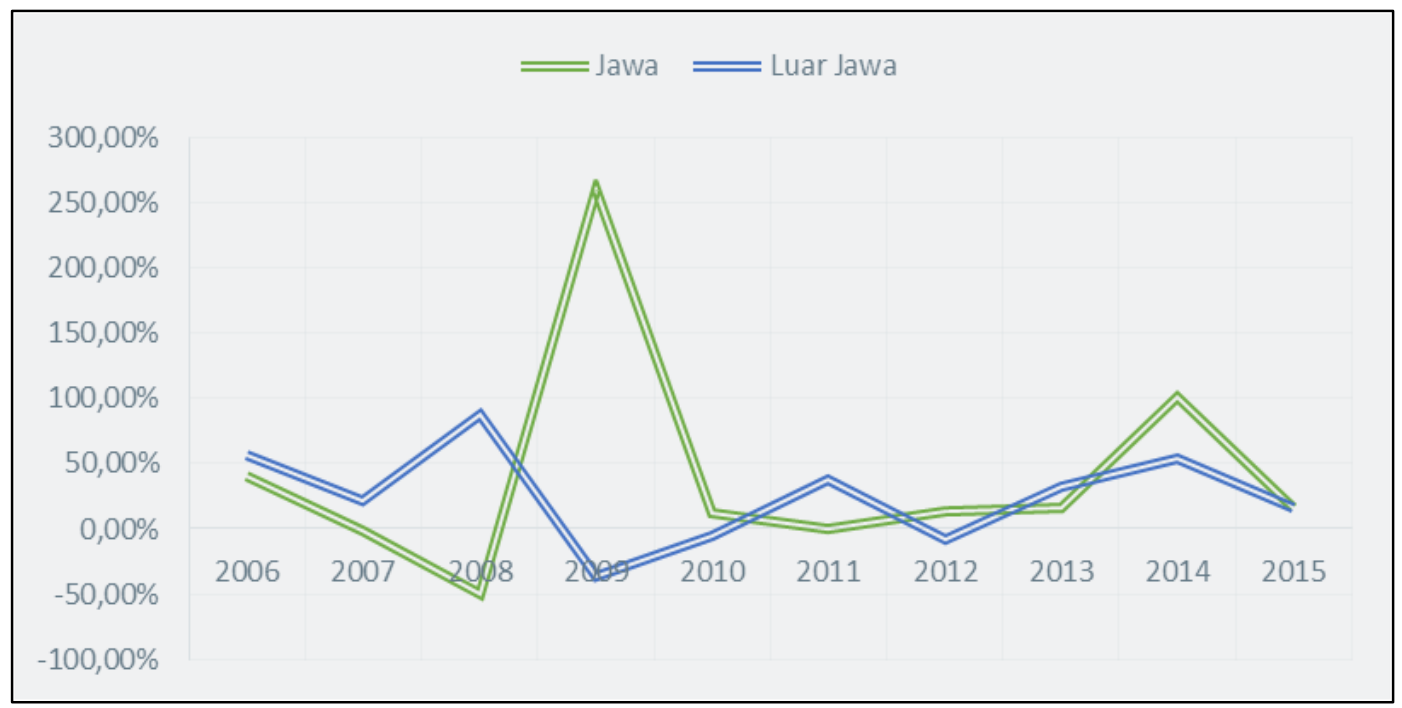

Gambar 1 Laju Pertumbuhan Kinerja Koperasi di Pulau Jawa Tahun 2006 - 2015

Berbagai program dan kebijakan yang mendukung perkembangan koperasi telah dilakukan oleh pemerintah, namun pada kenyataannya kinerja koperasi belum menunjukan kesuksesannya, Laju pertumbuhan kinerja koperasi di Pulau Jawa mengalami fluktuatif bahkan memiliki pertumbuhan negatif di tahun 2008 yaitu - 49,21\%.

Kondisi tersebut tidak sejalan dengan penelitian yang dilakukan Hendar dan Kusnadi (1999) dimana dalam era globalisasi koperasi diharapkan mampu bersaing karena koperasi memiliki keunggulan antara lain:

1. Penciptaan nilai tambah

2. Penciptaan Economies of scale

3. Bargaining position di pasar sebagai akibat bersatunya para produsen dalam koperasi

4. Kemampuan dalam menghadapi ketidakpastian (uncertainty), dan

5. Pemanfaatan inter-linkage market dan transaction cost sebagai akibat self control dan self management. 


\section{Rumusan Masalah}

Berdasarkan uraian latar belakang maka dirumuskan beberapa permasalahan dengan rincian sebagai berikut:

1. Bagaimana keunggulan komparatif koperasi di Pulau Jawa?

2. Bagaimana perkembangan dan kinerja koperasi di Pulau Jawa ?

3. Apakah faktor-faktor yang mempengaruhi kinerja koperasi di Pulau Jawa?

\section{Tujuan Penelitian}

Dari perumusan masalah yang telah diuraikan di atas, maka tujuan penelitian ini adalah sebagai berikut:

1. Menganalisis keunggulan komparatif koperasi di Pulau Jawa.

2. Mengkaji perkembangan dan kinerja koperasi di Pulau Jawa.

3. Menganalisis faktor-faktor yang mempengaruhi kinerja koperasi di Pulau Jawa.

\section{TINJAUAN PUSTAKA}

\section{Definisi Koperasi}

Koperasi adalah suatu badan usaha yang beranggotakan orangseorang atau badan hukum koperasi dengan melandaskan segala kegiatannya ber-dasarkan prinsip koperasi sekaligus sebagai gerakan ekonomi rakyat yang berdasar atas asas kekeluargaan (UU No 25 Tahun 1992 tentang Perkoperasian).

\section{Prinsip Koperasi}

Secara umum koperasi dapat dikelompokan berdasarkan tingkat dan luas cakupan operasional yaitu:

1 Koperasi primer, merupakan koperasi yang anggotaanggotanya terdiri dari orang seorang dengan jumlah anggota minimal 20 orang, yang mempunyai kesamaan aktivitas, kepentingan, tujuan dan kebutuhan ekonomi.

2 Koperasi sekunder, merupakan koperasi yang dibentuk oleh sekurang-kurangnya tiga koperasi yang berbadan hukum baik primer maupun sekunder.

Sedangkan koperasi berdasarkan sektor usahanya antara lain:

1 Koperasi Simpan Pinjam (KSP) ataupun Koperasi Kredit (Kopdit), adalah koperasi yang bergerak di bidang usaha simpanan dan pinjaman bagi anggotanya.

2 Koperasi Konsumen, adalah koperasi yang beranggotakan para konsumen dengan menjalankan kegiatan jual beli barang konsumsi. Contoh koperasi jenis ini yaitu koperasi karyawan dan koperasi pegawai, koperasi serba usaha dan koperasi unit desa.

3 Koperasi Produsen, adalah koperasi yang beranggotakan para pengusaha kecil, mikro dan menengah dengan menjalankan kegiatan pengadaan bahan baku dan penolong untuk anggotanya

4 Koperasi Pemasaran, adalah koperasi yang melakukan kegiatan penjualan produk/jasa koperasinya atau anggotanya. Selain itu dapat pula diartikan koperasi yang beranggotakan orang-orang yang mempunyai kegiatan di bidang pemasaran barang-barang dagangan.

5 Koperasi Jasa, adalah koperasi yang didirikan untuk memberikan pelayanan (jasa) kepada para anggotanya. 


\section{Prinsip-Prinsip Koperasi}

International Cooperative Allience (2002) merumuskan prinsip-prinsip koperasi adalah:

1 Koperasi merupakan perkumpulan sukarela, terbuka bagi semua orang yang mampu menggunakan jasajasa perkumpulan dan bersedia menerima tanggung jawab keanggotaan tanpa diskriminasi gender, sosial, rasial, politik, dan agama.

2 Koperasi dikendalikan oleh para anggotanya yang secara aktif berpartisipasi dalam penetapan kebijakan-kebijakan perkumpulan dan mengambil keputusankeputusan. Anggota koperasi menyumbang secara adil dan mengendalikan secara demokratis, modal dari koperasi mereka.

3 Koperasi bersifat otonom, merupakan perkumpulan yang menolong diri sendiri dan dikendalikan oleh anggotaanggotanya.

4 Koperasi menyelenggarakan pendidikan bagi anggotanya, para wakil yang dipilih, manajer dan karyawan, agar mereka dapat memberikan sumbangan yang efektif bagi perkembangan koperasi.

\section{Teori Keunggulan Komparatif dan Pembangunan Ekonomi Daerah}

Pembangunan ekonomi daerah merupakan fungsi dari potensi sumberdaya alam, tenaga kerja dan sumberdaya manusia, investasi modal, prasarana dan sarana pembangunan, transportasi dan komunikasi, komposisi industri, teknologi, situasi ekonomi dan perdagangan antar wilayah, kemampuan pendanaan dan pembiayaan pembangunan daerah, kewirausahaan, kelembagaan daerah dan lingkungan pembangunan secara luas (Arsyad, 1999).

Pembangunan ekonomi di suatu daerah berkaitan erat dengan potensi dan karakteristik yang dimilikinya yang biasanya berbeda dengan daerah lain. Adanya perbedaan potensi dan karakteristik yang dimiliki masingmasing daerah disebabkan oleh karena adanya perbedaan pada faktor geografis dan sumberdaya yang tersedia. Perbedaan tersebut menyebabkan produk-produk tertentu yang dihasilkan oleh suatu daerah mempunyai keunggulan dan kemampuan bersaing (comparative and competitive advantage) bila dibandingkan dengan produk yang sama yang dihasilkan oleh daerah lain.

Oleh karena adanya berbagai perbedaan antar daerah, maka keberhasilan pembangunan suatu daerah sangat ditentukan oleh kemampuan daerah itu sendiri dalam mengidentifikasi dan mengelola potensi dan sumberdaya ekonomi, seperti sumberdaya alam, sumberdaya manusia atau sektor ekonomi yang mempunyai keunggulan komperatif dan keunggulan kompetitif bila dibandingkan dengan daerah lain.

Menurut Arsyad (1999) permasalahan pokok dalam pembangunan daerah adalah terletak pada penekanan kebijakan-kebijakan pembangunan yang didasarkan pada kekhasan daerah yang bersangkutan(endogenous development) dengan menggunakan potensi sumber daya manusia. Orientasi ini mengarahkan pada pengambilan inisiatifinisiatif yang berasal dari daerah tersebut dalam proses pembangunan untuk menciptakan kesempatan kerja baru dan merangsang peningkatan ekonomi.

Sebelum berlakunya otonomi daerah, ketimpangan ekonomi regional di Indonesia disebabkan karena 
pemerintah pusat menguasai dan mengendalikan hampir sebagian besar pendapatan daerah yang ditetapkan sebagai penerimaan negara, termasuk pendapatan dari hasil sumber daya alam dari sektor pertambangan, perkebunan, kehutanan, dan perikanan atau kelautan. Akibatnya daerah-daerah yang kaya sumber daya alam tidak dapat menikmati hasilnya secara layak. Menurut pemikiran ekonomi klasik bahwa pembangunan ekonomi di daerah yang kaya sumber daya alam akan lebih maju dan masyarakatnya lebih makmur dibandingkan di daerah yang miskin sumber daya alam.

Hingga tingkat tertentu, anggapan ini masih bisa dibenarkan, dalam artian sumber daya alam harus dilihat sebagai modal awal untuk pembangunan yang selanjutnya harus dikembangkan terus. Untuk itu diperlukan faktor-faktor lain, diantaranya yang sangat penting adalah teknologi dan sumber daya manusia (Tambunan, 2001).

Perbedaan tingkat pembangunan yang di dasarkan atas potensi suatu daerah, berdampak terjadinya perbedaan sektoral dalam pembentukan Produk Domestik Regional Bruto (PDRB). Secara hipotesis dapat dirumuskan bahwa semakin besar peranan potensi sektor ekonomi yang memiliki nilai tambah terhadap pembentukan atau pertumbuhan PDRB di suatu daerah, maka semakin tinggi laju pertumbuhan PDRB daerah tersebut.

Berdasarkan pengalaman negaranegara maju, pertumbuhan yang cepat dalam sejarah pembangunan suatu bangsa biasanya berawal dari pengembangan beberapa sektor primer. Pertumbuhan cepat tersebut menciptakan efek bola salju terhadap sektor-sektor lainnya, khususnya sektor sekunder. Pembangunan ekonomi dengan mengacu pada sektor unggulan selain berdampak pada percepatan pertumbuhan ekonomi juga akan berpengaruh pada perubahan mendasar dalam struktur ekonomi. Pengertian sektor unggulan pada dasarnya dikaitkan dengan suatu bentuk perbandingan, baik itu perbandingan berskala internasional, regional maupun nasional. Pada lingkup internasional, suatu sektor dikatakan unggul jika sektor tersebut mampu bersaing dengan sektor yang sama dengan negara lain.

Sedangkan pada lingkup nasional, suatu sektor dapat dikategorikan sebagai sektor unggulan apabila sektor di wilayah tertentu mampu bersaing dengan sektor yang sama yang dihasilkan oleh wilayah lain, baik di pasar nasional ataupun domestik. Penentuan sektor unggulan menjadi hal yang penting sebagai dasar perencanaan pembangunan daerah sesuai era otonomi daerah saat ini, di mana daerah memiliki kesempatan dan kewenangan untuk membuat kebijakan yang sesuai dengan potensi daerah demi mempercepat pembangunan ekonomi daerah untuk peningkatan kemakmuran masyarakat.

Menurut Rachbini (2001) ada empat syarat agar suatu sektor tertentu menjadi sektor prioritas, antara lain:

1 Sektor tersebut harus menghasilkan produk yang mempunyai permintaan yang cukup besar, sehingga laju pertumbuhan berkembang cepat akibat dari efek permintaan tersebut;

2 Karena ada perubahan teknologi yang teradopsi secara kreatif, maka fungsi produksi baru bergeser dengan pengembangan kapasitas yang lebih luas;

3 Harus terjadi peningkatan investasi kembali dari hasilhasil produksi sektor yang menjadi prioritas tersebut, baik swasta maupun pemerintah;

4 Sektor tersebut harus berkembang, sehingga mampu memberi 
pengaruh terhadap sektor-sektor lainnya.

Data PDRB merupakan informasi yang sangat penting untuk mengetahui output pada sektor ekonomi dan melihat pertumbuhan di suatu wilayah tertentu (provinsi/kabupaten/kota). Dengan bantuan data PDRB, maka dapat ditentukannya sektor unggulan di suatu daerah atau wilayah. Sektor unggulan adalah satu grup sektor/subsektor yang mampu mendorong kegiatan ekonomi dan menciptakan kesejahteraan di suatu daerah terutama melalui produksi, ekspor dan penciptaan lapangan pekerjaan, sehingga identifikasi sektor unggulan sangat penting terutama dalam rangka menentukan prioritas dan perencanaan pembangunan ekonomi di daerah.

Manfaat mengetahui sektor unggulan, yaitu mampu memberikan indikasi bagi perekonomian secara nasional dan regional. Sektor unggulan dipastikan memiliki potensi lebih besar untuk tumbuh lebih cepat dibandingkan sektor lainnya dalam suatu daerah terutama adanya faktor pendukung terhadap sektor unggulan tersebut yaitu akumulasi modal, pertumbuhan tenaga kerja yang terserap, dan kemajuan teknologi. Penciptaan peluang investasi juga dapat dilakukan dengan memberdayakan potensi sektor unggulan yang dimiliki oleh daerah yang bersangkutan.

\section{Kinerja Koperasi}

Pengertian kinerja dalam Kamus Besar Bahasa Indonesia adalah (1) sesuatu, Sedangkan Siegel dan Shim (1994) memberikan batasan yang lebih rinci tentang kinerja yaitu pernyataan yang menyajikan ukuran hasil yang sebenarnya dari beberapa kegiatan pribadi atau kesatuan pada periode waktu yang sama. Oleh karena itu dapat ditarik suatu pengertian dari kinerja yaitu gambaran prestasi yang yang telah dicapai, selalu dibandingkan dengan ukuran standar dan sifatnya relative tergantung pada tinggi rendahnya standar yang digunakan.

Di dalam lingkungan dunia usaha, secara umum masih beranggapan bahwa laba merupakan salah satu tolak ukur dalam mengukur kinerja perusahaan. Sehingga perusahan yang labanya kecil dianggap berkinerja rendah, padahal ada aspek lain yang harus dinilai. Dengan demikian laba bukanlah satu-satunya tolak ukur dalam menilai kinerja. Perlu dipahami bahwa suatu perusahaan mempunyai tujuan utama dalam berusaha, oleh karena itu untuk menilai keberhasilan usaha perlu mengukur mengetahui apa yang diinginkan oleh perusahaan.

Koperasi merupakan salah satu bentuk badan usaha di Indonesia yang memiliki perbedaan dibandingkan degan badan usaha lain yang berorientasi ada keuntungan (profit oriented), dimana tujuan koperasi adalah memajukan kesejahteraan anggota melalui upaya-upaya kelompok secara mandiri dengan menerapkan sejumlah nilai, norma dan prinsipprinsip koperasi. Pengukuran kinerja koperasi mengacu harus pada tujuan pokoknya sekaligus juga harus mencerminkan berlakunya nilai, norma dan prinsip-prinsip yang mengikatnya.

Secara universal tujuan koperasi yaitu meningkatkan dan mengembangkan kondisi perekonomian rumah tangga anggota atau memajukan kesejahteraan anggota. Artinya tujuan operasional organisasi koperasi merupakan akumulasi dari tujuan ekonomi seluruh anggotanya. Semakin heterogen kepentingan dan aktivitas ekonomi anggotanya akan menjadi semakin kompleks tugas-tugas yang harus dijalankan oleh koperasi. Dengan demikian tujuan ekonomi koperasi dapat 
dioperasionalisasikan sebagai meningkatkan pendapatan anggota. Bila koperasi berhasil meningkatkan pendapatan anggota maka kesejahteraan ekonomi anggota akan meningkat.

Menurut Alwi (2001) secara teoritis tujuan pengukuran kinerja suatu usaha dikategorikan sebagai suatu yang bersifat evaluation dan development yang harus menyelesaikan: (1) Hasil penilaian digunakan sebagai dasar pemberian kompensasi (2) Hasil penilaian digunakan sebagai staffing decision (3) Hasil penilaian digunakan sebagai dasar mengevaluasi sistem seleksi.

Koperasi memiliki jatidiri yang berbeda dengan pelaku ekonomi lainnya (PT, CV dan sebagainya) dimana tujuan utama koperasi yaitu memajukan kesejahteraan anggota melalui upayaupaya kelompok secara mandiri dengan menerapkan nilai, norma dan prinsip koperasi. Salah satu indikator yang dapat digunakan dalam melihat kinerja koperasi yaitu sisa hasil usaha (SHU), dimana SHU dapat mengukur tujuan utama keperasi yaitu kesejahteraan anggota koperasi.

\section{Penelitian Terdahulu}

Berbagai macam penelitian tentang perkoperasian telah banyak dilakukan baik di dalam negeri maupun luar negeri. Susilo (2004) dalam penelitian yang berjudul "Analisis Faktor Yang Mempengaruhi Keberhasilan Usaha Koperasi Pegawai Negeri Di Kabupaten Karanganyar" dengan menggunakan metode analisis regresi linier berganda. Hasil penelitian menunjukan bahwa untuk hasil volume usaha berpengaruh terhadap sisa hasil usaha sehingga hipotesis yang diajukan terbukti. Untuk variabel jumlah anggota, jumlah simpanan, dan modal luar tidak berpengaruh secara signifikan terhadap sisa hasil usaha sehingga hipotesis yang diajukan tidak terbukti.

Situmorang (2008) dalam penelitian yang berjudul "Peringkat Provinsi dalam Membangun Ekonomi Koperasi Analisis Berdasarkan Indeks PEKR". Data yang digunakan yaitu volume usaha koperasi regional, volume usaha koperasi nasional, PDRB dan PDB. Hasil penelitian menunjukan provinsi yang memiliki indeks PEKR terbesar yaitu Gorontalo $(5,6086)$, Bali $(3,5734)$ dan Jawa Timur $(2,3627)$, artinya ketiga provinsi ini memiliki kemampuan yang lebih besar dibandingkan dengan provinsi lain dalam membangun koperasi di Indonesia.

Ayuk (2012) dalam penelitian yang berjudul " Pengaruh Jumlah Anggota, Jumlah Simpanan, Jumlah Pinjaman dan Jumlah Modal Kerja Terhadap Sisa Hasil Usaha (SHU) Koperasi Simpan Pinjam (KSP) di Kabupaten Badung Provinsi Bali". Data yang digunakan sebanyak 36 koperasi simpan pinjam dari pada tahun 20072011 dengan metode panel data. Hasil analisis data diketahui bahwa jumlah anggota, jumlah simpanan, jumlah pinjaman dan jumlah modal kerja secara simultan berpengaruh signifikan terhadap sisa hasil usaha koperasi simpan pinjam di Kabupaten Badung. Variabel jumlah modal kerja berpengaruh paling dominan terhadap sisa hasil usaha koperasi simpan pinjam di Kabupaten Badung.

Sujianto (2012) dalam penelitian yang berjudul "Variabel-Variabel yang Mempengaruhi Kinerja Koperasi Pondok Pesantren di Kabupaten Tulungagung”. Data yang digunakan sebanyak 320 responden anggota koperasi dari 35 Koperasi Pondok Pesantren di Kabupaten Tulungagung dengan menggunakan teknik penarikan sampel dan dianalisis menggunakan 
model persamaan Linear Structural Relationships. Hasil penelitian menunjukan bahwa moderenitas Kyai dan kinerja pengurus koperasi memberikan kontribusi positif terhadap tingkat pastisipasi anggota koperasi, serta pembinaan anggota, kinerja pengurus dan partisipasi anggota berpengaruh positif terhadap kinerja Koperasi Pondok Pesantren.

\section{Hipotesis Penelitian}

Berdasarkan landasan teori dan penelitian terdahulu, maka hipotesis untuk menjawab tujuan penelitian ini yaitu

1. Jumlah koperasi aktif berpengaruh positif terhadap kinerja koperasi.
2. Jumlah tenaga kerja koperasi berpengaruh positif terhadap kinerja koperasi.

3. Jumlah modal sendiri koperasi berpengaruh positif terhadap kinerja koperasi.

4. Jumlah modal luar koperasi berpengaruh positif terhadap kinerja koperasi.

5. PDRB berpengaruh positif terhadap kinerja koperasi.

\section{Kerangka Pemikiran}

Berdasarkan keterkaitan antara perumusan masalah, tujuan penelitian dan metode penelitian maka secara sistematis kerangka pemikiran operasional dapat dilihat pada Gambar1.

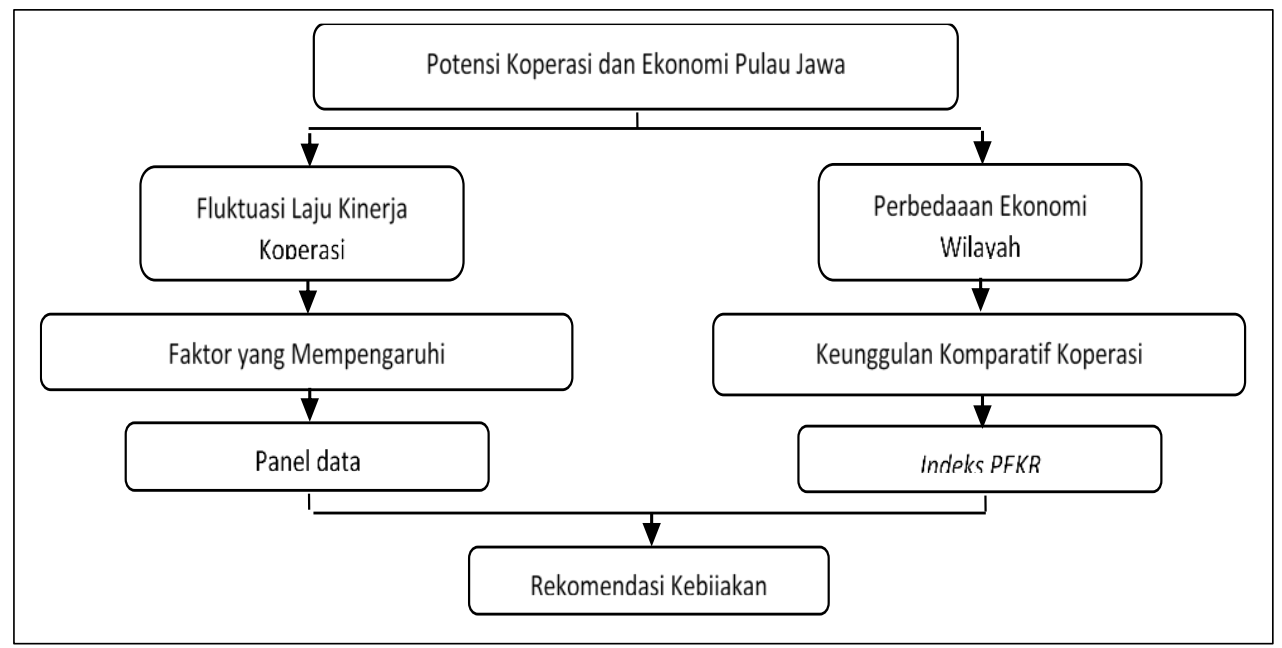

Gambar 2 Kerangka Penelitian

\section{METODE PENELITIAN}

\section{Jenis dan Sumber Data}

Penelitian ini menggunakan data sekunder dengan jenis data panel yaitu menggabungkan data deret waktu dengan data individu. Data deret waktu (time series) dari periode tahun 2003 sampai dengan 2015 sedangkan data individu (cross section) yaitu 6 Provinsi di Pulau Jawa. Data diambil dari Badan Pusat Statistik Republik Indonesia
(BPS-RI), Kementerian Koperasi dan Usaha Kecil Menengah, selain itu referensi diambil juga dari jurnal, buku dan internet.

\section{Metode Analisis}

Metode analisis yang digunakan dalam penelitian ini adalah analisis deskriptif dan analisis kuantitatif. Analisis deskriptif digunakan untuk menjelaskan perkembangan dan kinerja koperasi di Pulau Jawa. Analisis secara 
kuantitatif digunakan untuk menganalisis keunggulan komparatif koperasi di Pulau Jawa dengan menggunakan metode Indeks PEKR, sedangkan untuk menganalisis faktor-faktor yang mempengaruhi kinerja koperasi di Pulau Jawa menggunakan metode regresi panel data. Perangkat lunak yang digunakan untuk proses pengolahan adalah Microsoft Excel 2007 dan Eviews 8 .

\section{Indeks PEKR}

Untuk mengetahui kemampuan provinsi dalam pengembangan ekonomi koperasi digunakan metode Indeks Performa Ekonomi Koperasi Regional (IPEKR). Secara metode IPEKR adalah perbandingan antara rasio nilai ekonomi koperasi regional dan nasional dengan rasio ekonomi regional dan nasional. Pendekatan analisis berdasarkan Indeks PEKR tersebut dirumuskan dalam persamaan berikut:

$$
\text { IPEKR }=\frac{\text { UEKR }}{\text { UER }}
$$

Dimana UEKR = ukuran ekonomi koperasi regional dan UER = ukuran ekonomi regional. IPEKR berada antara nol dan tak terhingga (IPEKR $\geq 0$ ). Bila IPEKR $<1$ maka performa atau rating regional rendah, dengan kata lain pengembangan ekonomi koperasi di bawah kemampuan ekonomi regionalnya. Bila IPEKR $>1$ maka performa atau rating regional tinggi, atau dengan kata lain pengembangan ekonomi koperasi di atas kemampuan ekonomi regionalnya. Berdasarkan IPEKR, pemeringkatan daerah dapat dilakukan. Oleh karena itu, peringkat daerah dalam ekonomi koperasi tergantung pada besaran IPEKR tersebut (Situmorang, 2012).

\section{Panel Data}

Data panel merupakan bagian dari pengumpulan gabungan dua jenis bentuk data yaitu time series dan cross section. Penggunaaan data panel dilakukan bila dalam suatu penelitian ditemukan keter-batasan data baik dalam bentuk penga-matan waktu maupun dalam bentuk pengamatan objek. Kedua kondisi tersebut dapat diatasi dengan mengguna-kan data panel yang bertujuan untuk memperoleh hasil estimasi yang lebih baik (efisien). Model panel data mampu meningkatkan jumlah pengamatan sehi-ngga terjadi peningkatan derajat bebas dan mampu menghasilkan penduga parameter yang lebih efisien. Metode panel data terdiri dari tiga jenis model antara lain:

1. Model Pooled

Model pooled yaitu model yang didapatkan dengan mengkombinasikan atau mengumpulkan semua data cross section dan time series. Model data ini kemudian di duga dengan menggunakan Ordinary Least Square (OLS).

2. Model Fixed Effect

Model Efek Tetap yaitu model yang di dapatkan dengan mempertimbangkan bahwa peubah-peubah yang dihilangkan dapat mengakibat-kan perubahan dalam interesep-interesep cross section dan time series.

3. Model Random Effect

Penambahan variabel dummy akan dapat mengurangi banyaknya derajat kebebasan yang pada akhirnya akan mengurangi efisiensi dari parameter yang diestimasi. Untuk mengatasi masalah tersebut maka kita bisa menggunakan Model Efek Acak (Random Effect).

\section{Perumusan Model}

Persamaan umum yang digunakan dalam penelitian ini untuk menganalisis faktor-faktor yang mempengaruhi kinerja koperasi di Pulau Jawa sebagai berikut: 


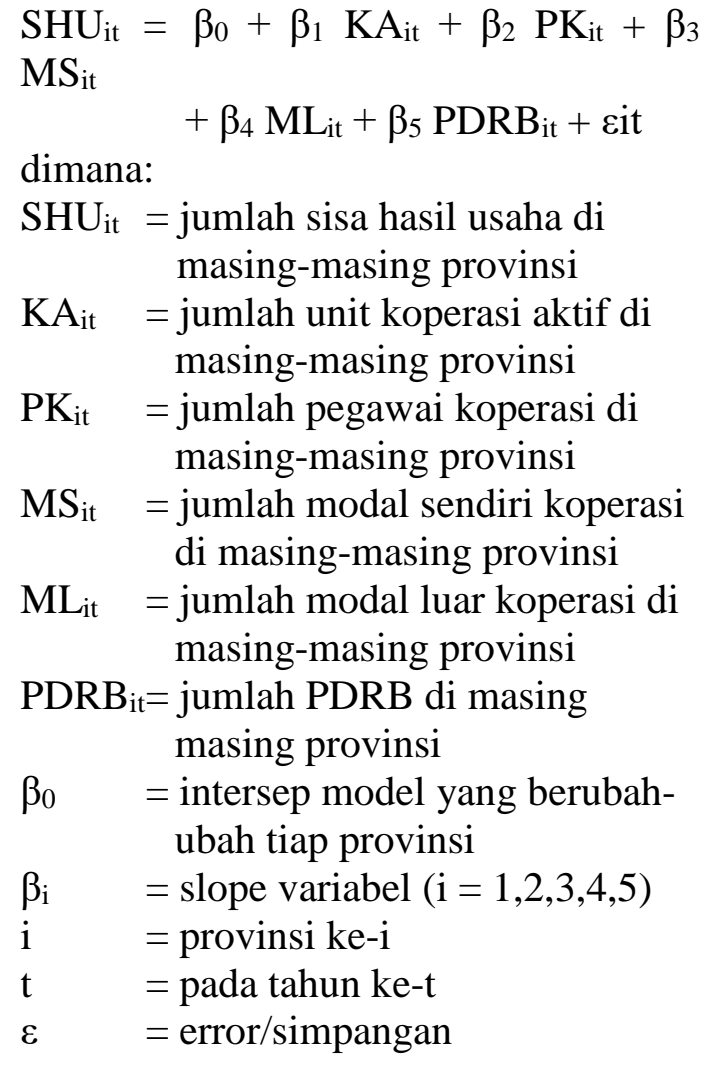

\section{PEMBAHASAN}

\section{Analisis Keunggulan Komparatif Koperasi Di Pulau Jawa}

Berdasarkan Indeks PEKR tahun 2011 provinsi di Pulau Jawa yang memiliki keunggulan komparatif dalam pembangunan koperasi adalah Provinsi DI Yogyakarta, Jawa Tengah dan Jawa Timur dengan nilai Indeks PEKR > 1 dengan kata lain pengembangan ekonomi koperasi di atas kemampuan ekonomi regionalnya. DI Yogyakarta merupakan provinsi di Pulau Jawa yang paling efisien dalam pembangunan ekonomi koperasi tahun 2011 dengan nilai Indeks PEKR 2,563 yang artinya setiap setiap $1 \%$ pembangunan ekonomi regional akan menciptakan 2,563\% pembangunan ekonomi koperasi regionalnya. Nilai Indeks PEKR Tahun 2011 secara lengkap dapat dilihat pada Gambar 2.

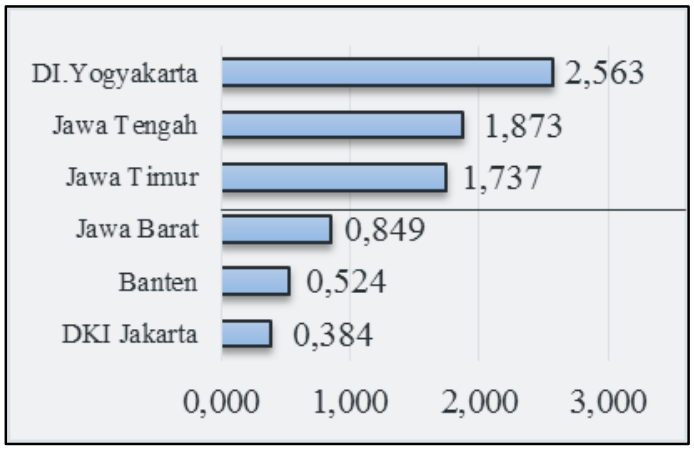

Gambar 2 Indeks PEKR Tahun 2011

Berdasarkan Indeks PEKR tahun 2012 provinsi di Pulau Jawa yang memiliki keunggulan komparatif dalam pembangunan koperasi adalah Provinsi Jawa Tengah, DI Yogyakarta, dan Jawa Timur dengan nilai Indeks PEKR > 1 dengan kata lain pengembangan ekonomi koperasi di atas kemampuan ekonomi regionalnya. Jawa Tengah merupakan provinsi di Pulau Jawa yang paling efisien dalam pembangunan ekonomi koperasi tahun 2012 dengan nilai Indeks PEKR 2,5639, yang artinya setiap setiap $1 \%$ pembangunan ekonomi regional akan menciptakan 2,5629\% pembangunan ekonomi koperasi regionalnya. Nilai Indeks PEKR Tahun 2012 secara lengkap dapat dilihat pada Gambar 3.

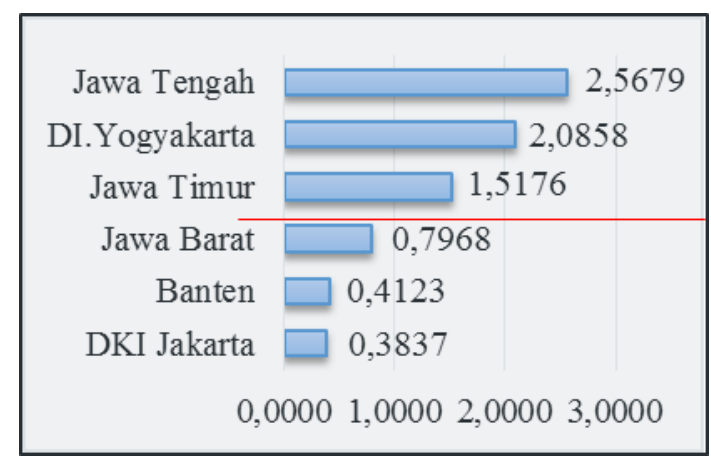

Gambar 3 Indeks PEKR Tahun 2012

Berdasarkan Indeks PEKR tahun 2013, hanya dua provinsi di Pulau Jawa yang memiliki keunggulan komparatif dalam pembangunan ekonomi koperasi yaitu provinsi di Pulau Jawa yang 
memiliki keunggulan komparatif dalam pembangunan ekonomi koperasi yaitu Jawa Tengah dan DI Yogyakarta. Pada Tahun 2013 Provinsi Jawa Timur mengalami penurunan jumlah omset atau volume usaha koperasi sehingga tidak memiliki keunggulan komparatif dalam pembangunan ekonomi koperasi (Indeks PEKR 0,7736 < 1). Nilai Indeks PEKR Tahun 2013 secara lengkap dapat dilihat pada Gambar 4.

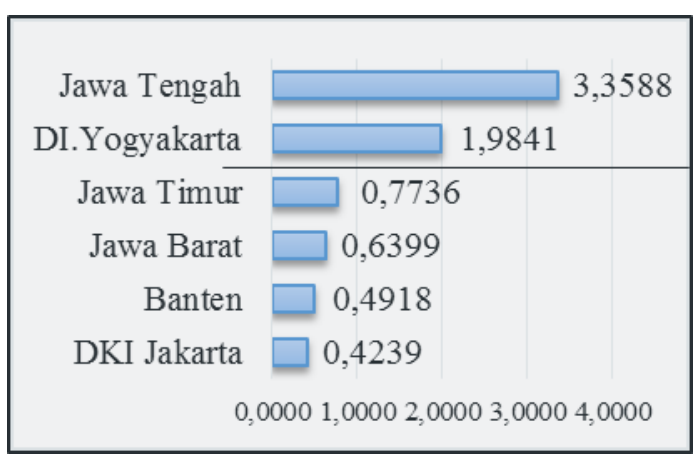

Gambar 4 PEKR Tahun 2013

Berdasarkan Indeks PEKR tahun 2014 provinsi di Pulau Jawa yang tidak memiliki keunggulan komparatif dalam pembangunan koperasi adalah Provinsi Jawa Barat, Banten dan DKI Jakarta dengan nilai Indeks PEKR $<1$. DKI Jakarta merupakan provinsi di Pulau Jawa yang paling tidak efisien dalam pembangunan ekonomi koperasi tahun 2014 dengan nilai Indeks PEKR 0,5207, yang artinya setiap setiap $1 \%$ pembangunan ekonomi regional hanya akan menciptakan $0,5207 \%$ pembangunan ekonomi koperasi regionalnya. Nilai Indeks PEKR Tahun 2014 secara lengkap dapat dilihat pada Gambar 5.

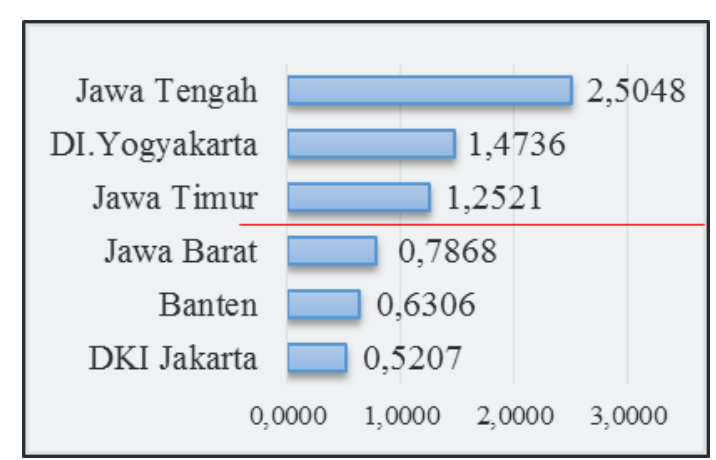

Gambar 5 Indeks PEKR Tahun 2014

Berdasarkan Indeks PEKR tahun 2015 provinsi di Pulau Jawa yang memiliki keunggulan komparatif dalam pembangunan koperasi adalah Provinsi Jawa Timur, Jawa Tengah dan DI Yogyakarta, dengan nilai Indeks PEKR $>1$. Jawa Timur merupakan provinsi di Pulau Jawa yang paling efisien dalam pembangunan ekonomi koperasi tahun 2015 dengan nilai Indeks PEKR 2,6482, yang artinya setiap setiap $1 \%$ pembangunan ekonomi regional akan menciptakan 2,6482\% pem-bangunan ekonomi koperasi regional-nya. Nilai Indeks PEKR Tahun 2015 secara lengkap dapat dilihat pada Gambar 2.

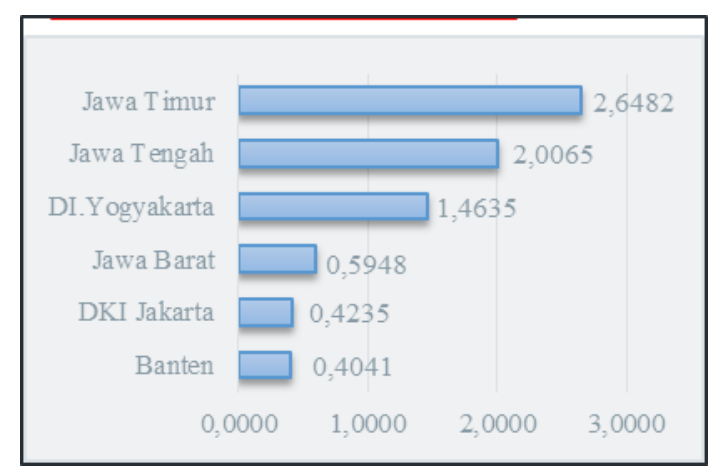

Gambar 6 Indeks PEKR Tahun 2015

Berdasarkan perkembangan Indeks PEKR dari Tahun 2011 hingga Tahun 2015, provinsi di Pulau Jawa yang tidak memiliki keunggulan komparatif dalam pembangunan ekonomi koperasi adalah Jawa Barat, DKI Jakarta dan Banten dengan nilai Indeks PEKR $<1$ dengan kata lain 
pengembangan ekonomi koperasi di bawah kemampuan ekonomi regionalnya. Oleh karena itu untuk mendorong provinsi agar memiliki keunggulan komparatif koperasi, pemerintah harus menerapkan kebijakan yang mendorong pengembangan koperasi khususnya yang dapat meningkatkan omset atau volume usaha koperasi seperti menciptakan iklim usaha yang kondusif. Selain itu koperasi sebagai pelaku usaha juga harus memiliki kemampuan melakukan diversifikasi usaha, meningkatkan efisiensi untuk menekan biaya, merespon dengan cepat keinginan konsumen, dan membangun jaringan yang luas.

\section{Analisis Perkembangan dan Kinerja Koperasi di Pulau Jawa}

$\begin{array}{lcrr} & \text { Partisipasi anggota } & \text { koperasi } \\ \text { sangat mempunyai peranan } & \text { penting } \\ \text { dalam } & \text { sebuah koperasi } & \text { karena }\end{array}$ kekuasaan tertinggi ada dalam rapat anggota. Jumlah anggota koperasi terbesar Tahun 2015 yaitu di Provinsi Jawa Tengah dengan jumlah sebanyak 7.808.978 anggota. Selain itu jumlah anggota koperasi di Pulau Jawa sangat mendominasi yaitu sebanyak 24.267 .130 anggota (64,22\%) jika dibandingkan dengan jumlah anggota koperasi di Indonesia 37.783160 anggota Tahun 2015. Secara umum jumlah anggota koperasi di Provinsi Jawa Timur, Jawa Tengah dan Jawa Barat mengalami pertumbuhan positif tiap tahunnya dari tahun 2011 sampai dengan tahun 2015. Sedangkan Jumlah anggota koperasi di DKI Jakarta, DI Yogyakarta dan Banten cenderung stagnan dari tahun 2011 sampai tahun 2015. Perkembangan jumlah anggota koperasi tiap provinsi di Pulau Jawa Tahun 2011-2015 secara lengkap dapat dilihat pada Gambar 7.

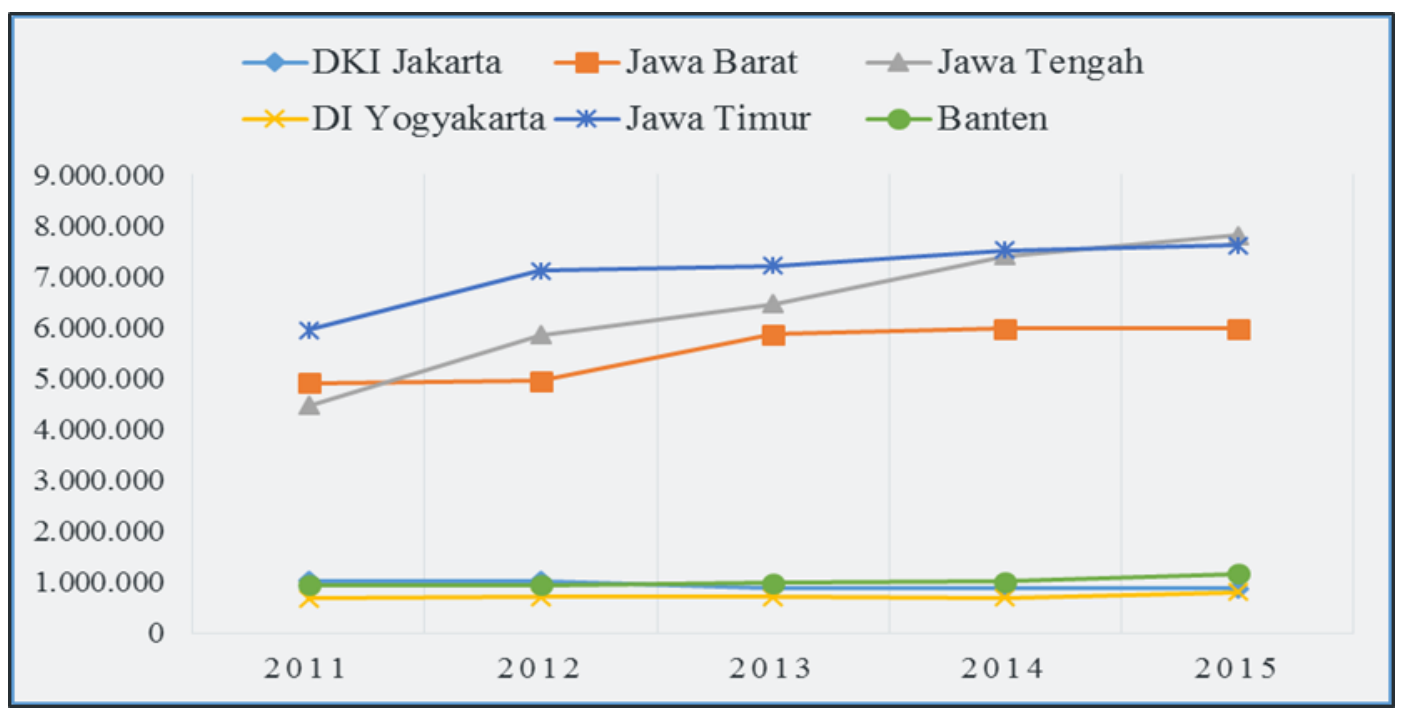

Gambar 7 Anggota Koperasi Tiap Provinsi di Pulau Jawa Tahun 2011 - 2015

Oleh karena itu untuk meningkatkan jumlah anggota koperasi diperlukan komitmen dari semua unsur baik pemerintah maupun koperasi itu sendiri agar membangun citra yang baik sehingga akan menarik minat masyarakat untuk menjadi anggota koperasi.

Berdasarkan data dari Kementerian Koperasi dan UKM bahwa persentase koperasi tidak aktif di Pulau Jawa cukup tergolong tinggi. Pada tahun 2015 
jumlah koperasi tidak aktif terbanyak adalah Provinsi Jawa Barat sebanyak $34.52 \%$, sedangkan Provinsi Jawa Timur memiliki jumlah koperasi tidak aktif dalam jumlah paling sedikit yaitu $11,90 \%$. Kondisi ini dapat terlihat pada Gambar 8.

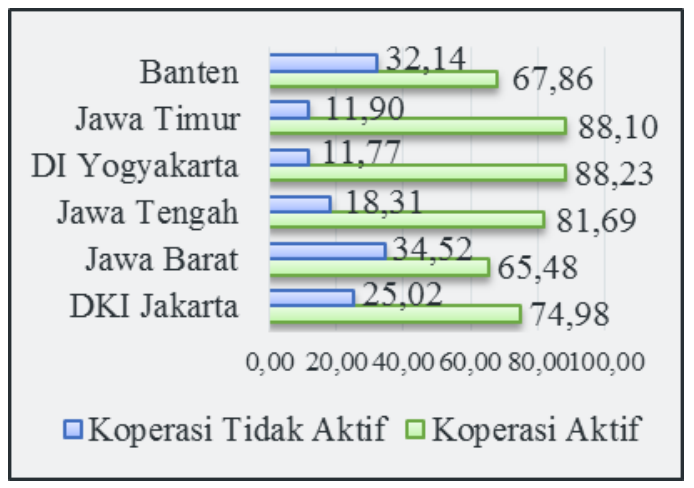

Gambar 8 Perbandingan Koperasi Aktif dan Tidak Aktif Tiap Provinsi di Pulau Jawa Tahun 2015

Salah satu unsur yang membuat citra koperasi belum cukup baik di masyarakat adalah banyaknya koperasi yang tidak aktif, koperasi tersebut tidak pernah melakukan rapat anggota tahunan bahkan ada koperasi yang tercatat memiliki badan hukum namun kegiatan usaha sudah tidak berjalan lagi. Merespon kenyataan yang ada di masyarakat, Kementerian Koperasi dan UKM sejak tahun 2015 berkomitmen melakukan pembinaan kepada koperasi agak koperasi kembali aktif dalam menjalankan usahanya. Apabila koperasi memang sudah tidak bisa di aktifkan kembali maka harus dilakukan pembubaran koperasi sesuai Pasal 32 pada Peraturan Menteri Koperasi dan UKM Nomor 10/Per/MKUKM/IX/2015 tentang Kelembagaan Koperasi.

Dalam Pasal 41 Undang-Undang Nomor 25 Tahun 1992 disebutkan bahwa modal koperasi terdiri dari modal sendiri dan modal pinjaman atau modal luar. Modal sendiri dapat berasal dari: (1) simpanan pokok, (2) simpanan wajib, (3) dana cadangan, dan (4) hibah. sedangkan modal pinjaman atau modal luar dapat berasal dari: (1) anggota, misalnya simpanan sukarela dan deposito, (2) koperasi lainnya dan atau anggota, (3) bank dan lembaga keuangan lainnya, (4) penerbitan obligasi dan surat hutang lainnya, dan (5) sumber lain yang sah.

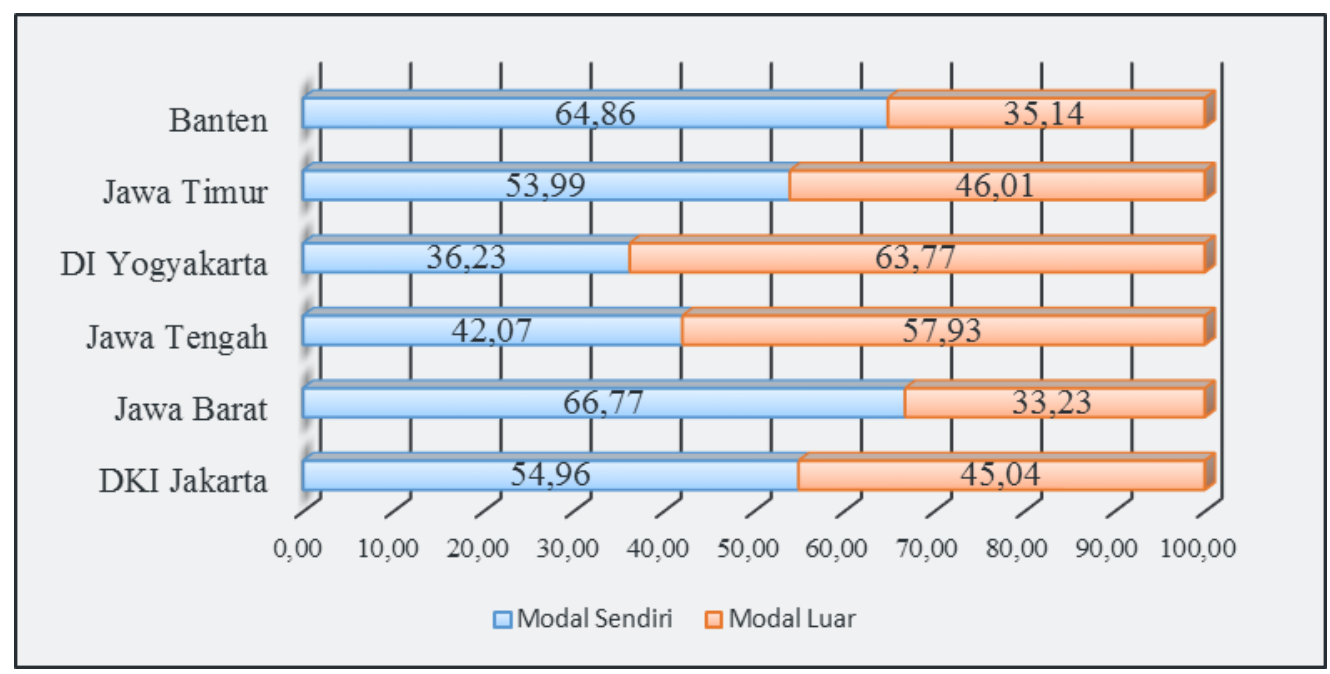

Gambar 9 Perbandingan Modal Sendiri dan Modal Luar Koperasi Tiap Provinsi di Pulau Jawa Tahun 2015 
Pada Tahun 2015 Provinsi DI Yogyakarta memiliki proporsi modal sendiri koperasi hanya sebesar $36,23 \%$ lebih kecil dibandingkan dengan modal luar koperasi sebesar 63,77\%. Begitu juga dengan Provinsi Jawa Tengah memiliki proporsi modal sendiri koperasi hanya sebesar $42,07 \%$ sedangkan modal luar koperasi sebesar 57,93\%. Partisipasi aktif dari anggota koperasi sangat dibutuhkan dalam rangka meningkatkan permodalan bagi koperasi. Perkembangan permodalan koperasi secara lengkap dapat dilihat pada Gambar 9.

Laju pertumbuhan kinerja koperasi di Pulau Jawa dalam kurun waktu tahun 2006 sampai dengan tahun 2015 secara umum mengalami pertumbuhan yang positif walaupun pertumbuhannya sedikit berfluktuatif. Pada tahun 2008 terjadi pertumbuhan kinerja koperasi yang negatif mencapai $-49,21 \%$. Pertumbuahn kinerja koperasi di Pulau Jawa secara lengkap dapat dilihat pada Gambar 10.

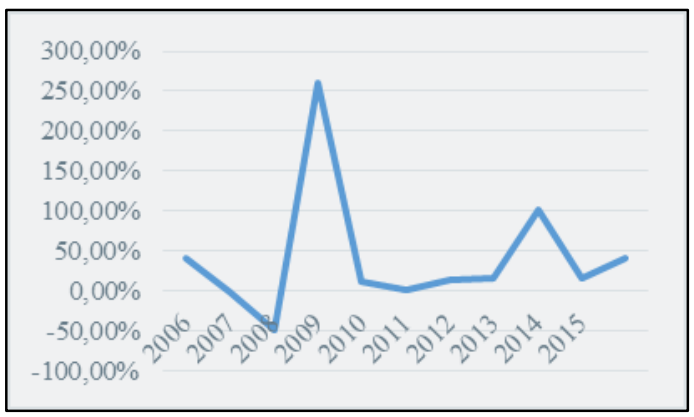

Gambar 10 Laju Pertumbuhan Kinerja Koperasi di Pulau Jawa Tahun 2006 - 2015

Untuk mendorong pengembangan, pemberdayaan dan peningkatan daya saing koperasi, pemerintah harus lebih mempertajam program dan kegiatannya serta diperlukan komitmen yang kuat agar koperasi dapat tumbuh dengan baik dan berkesinambungan.

\section{Analisis Faktor yang Mempengaruhi Kinerja Koperasi Di Pulau Jawa}

Dari ketiga model yaitu Model Pooled, Model Fixed Effect, dan Model Random Effect, berdasarkan hasil uji-uji yang telah dilakukan (Uji Chow dan Uji Hausman) maka didapatkan model terbaik yaitu Model Fixed Effect. Dari lima variabel yang diestimasi, empat variabel signifikan dan satu variabel yang tidak signifikan dalam model.

Setelah menentukan model terbaik dengan uji pemilihan model, selanjutnya didapatkan hasil estimasi Model Fixed Effect yang dapat menjelaskan faktorfaktor yang mempengaruhi kinerja koperasi di Pulau Jawa. Model ini terlebih dahulu harus dilakukan uji asumsi sebagai syarat agar diperoleh penduga yang baik. Berdasarkan hasil estimasi model Fixed Effect, nilai uji-F signifikan pada taraf nyata $5 \%$ karena probabilitas F-stat menunjukkan nilai 0,0000 yang lebih kecil dari nilai $\alpha=5 \%$ $(0,005)$, hal ini menunjukkan bahwa minimal ada satu variabel yang berpengaruh nyata pada model. Selain itu model ini memiliki nilai $\mathrm{R}$-squared yang tinggi yaitu sebesar 0.98 yang artinya sebesar 98\% kinerja koperasi dapat dijelaskan oleh variabel-variabel di dalam model, sementara itu sisanya dijelaskan oleh variabel lain di luar model.

Berdasarkan hasil estimasi model yang ditunjukan pada tabel 1 di bawah. Variabel-variabel yang mempengaruhi kinerja koperasi di Pulau Jawa adalah variabel jumlah koperasi aktif, modal sendiri, pegawai koperasi dan PDRB, sedangkan variabel modal luar secara statistik tidak mempengaruhi kinerja koperasi di Pulau Jawa. 
Tabel 1 Hasil Estimasi Faktor-Faktor yang Mempengaruhi Kinerja Koperasi di Pulau Jawa

\begin{tabular}{lcccc}
\hline Variable & Coefficient & Std. Error & $t$-Statistic & Prob. \\
\hline KA & 0,913277 & 0,120737 & 7,564195 & $0,0000^{*}$ \\
PK & 0,402281 & 0,065789 & 6,114743 & $0,0000^{*}$ \\
ML & $-0,031173$ & 0,064040 & $-0,486774$ & 0,6280 \\
MS & 0,244647 & 0,068010 & 3,597242 & $0,0006^{*}$ \\
PDRB & 1,230704 & 0,220496 & 5,581530 & $0,0000^{*}$ \\
C & $-25,88604$ & 3,129250 & $-8,272281$ & $0,0000^{*}$ \\
\hline & R-Squared $: 0,98$ & & Durbin-Watson Stat $: 1,86$ \\
\hline
\end{tabular}

Keterangan : *signifikan pada taraf nyata $\alpha(5 \%)$

Variabel jumlah koperasi aktif berhubungan positif dan signifikan secara nyata pada taraf $5 \%$ terhadap kinerja koperasi, artinya jika terjadi peningkatan jumlah koperasi aktif sebesar $1 \%$ maka kinerja koperasi akan meningkat sebesar $0,913277 \%$, ceteris paribus. Hal ini sesuai dengan hipotesis karena jika koperasi aktif meningkat maka hal ini bearti aktivitas di dalam koperasi seperti memenuhi kebutuhan jual beli barang bagi anggotanya serta meminjam dan menabung di koperasi yang pada akhirnya akan meningkatkan kinerja koperasi.

Variabel pegawai koperasi yang terdiri dari manager dan karyawan berhubungan positif dan signifikan secara nyata pada taraf $5 \%$ terhadap kinerja koperasi, artinya jika terjadi peningkatan jumlah pegawai koperasi sebesar $1 \%$ maka kinerja koperasi akan meningkat sebesar $0,402281 \%$, ceteris paribus. Hal ini sesuai dengan hipotesis karena dengan adanya peningkatan jumlah tenaga kerja koperasi (manager dan karyawan) maka pelayanan usaha bagi anggota koperasi semakin baik dan menarik minat orang untuk menjadi anggota koperasi dan berdampak terhadap kinerja koperasi yang semakin baik.

Variabel modal sendiri berhubungan positif dan signifikan secara nyata pada taraf $5 \%$ terhadap kinerja koperasi, artinya jika terjadi peningkatan jumlah modal sendiri pada koperasi sebesar 1\% maka kinerja koperasi akan meningkat sebesar $0,244647 \%$, ceteris paribus. Hal ini sesuai dengan hipotesis bahwa modal koperasi bersumber dari anggota dan untuk anggota melalui simpanan pokok, simpanan wajib, dana cadangan dan hibah. Modal tersebut seyogyanya digunakan seoptimal mungkin untuk memenuhi berbagai kebutuhan usaha dalam koperasi diantaranya unit simpan pinjam dan penyediaan barang-barang komsumsi. Diharapkan seluruh anggota koperasi memanfaatkan fasilitas tersebut seefektif mungkin sehingga transaksi yang dilakukan di dalam koperasi semakin banyak dan pada akhirnya meningkatkan keuntungan bagi koperasi.

Variabel PDRB berhubungan positif dan signifikan secara nyata pada taraf 5\% terhadap kinerja koperasi, artinya jika terjadi peningkatan PDRB sebesar 1\% maka kinerja koperasi akan meningkat sebesar $1,230704 \%$, ceteris paribus. Hal ini sesuai dengan hipotesis karena dengan besarnya PDRB suatu daerah mengindikasikan besarnya pendapatan masyaratakatnya sehingga, masyarakat yang termasuk anggota koperasi akan memiliki kemampuan besar dalam memberikan simpanan pokok dan simpanan wajib koperasi 
sehingga berdampak pada meningkatnya kinerja pada koperasi.

\section{KESIMPULAN DAN SARAN}

\section{Kesimpulan}

Berdasarkan hasil penelitian maka diperoleh simpulan sebagai berikut:

1. Provinsi Jawa Tengah, DI Yogyakarta dan Jawa Timur memiliki keunggulan komparatif dalam pembangunan ekonomi koperasi pada tahun 2011-2015 dengan Indeks PEKR > 1 .

2. Faktor yang secara signifikan berpengaruh positif terhadap kinerja koperasi adalah jumlah koperasi aktif, jumlah pegawai koperasi, modal sendiri koperasi dan PDRB.

\section{Saran}

Adapun saran yang dapat diberikan yaitu :

1. Diperlukan pendidikan dan pelatihan perkoperasian bagi anggota dan pengurus koperasi sehingga berdampak positif terhadap kinerja koperasi.

2. Memfasilitasi koperasi dalam mengakses pembiayaan dan perluasan skema pembiayaan bagi koperasi

3. Pemerintah harus memfokuskan kebijakan pada wilayah yang tidak memiliki keunggulan komparatif dalam membangun dan mendayagunakan koperasi.

\section{DAFTAR PUSTAKA}

Alwi S. 2001, Manajemen Sumber Daya Manusia, Strategi Keunggulan Kompetitif, Badan Penerbit Fakultas Ekonomi, Yogyakarta.

Arsyad L. 1999. Pengantar Perencanaan dan Pembangunan
Ekonomi Daerah Edisi Pertama. Yogyakarta (ID): BPFE.

Ayuk NMT. 2012. "Pengaruh Jumlah Anggota, Jumlah Simpanan, Jumlah Pinjaman dan Jumlah Modal Kerja Terhadap Sisa Hasil Usaha (SHU) Koperasi Simpan Pinjam (KSP) di Kabupaten Badung Provinsi Bali”. Jurnal]. Denpasar (ID) : Fakultas Ekonomi Universitas Udayana.

[BPS] Badan Pusat Statistika. 2015. http://www.bps.go.id. Jakarta (ID):BPS. [2016 Juni 7]

Hendar, Kusnadi. 1999. Ekonomi Koperasi Untuk Perguruan Tinggi. Jakarta (ID): Lembaga Penerbit Universitas Indonesia.

[ICA] International Cooperative Alliance. 2002. Jati Diri Koperasi ICA Cooperative Identity Statement Prinsip-Prinsip Koperasi Unduk Abad Ke- 20. Jakarta (ID) : Lembaga Studi Pengembangan Perkoperasian Indonesia (LSP2I).

[Kemenkop] Kementerian Koperasi dan UKM.

2015. http://www.depkop.go.id [2016 April 14].

Rachbini. 2001. Pembangunan Ekonomi \& Sumber Daya Manusia. Jakarta (ID): Gramedia Widiasarana Indonesia.

Siegel JG, Shim JK. 1994. Kamus Istilah Akuntansi. Jakarta (ID) : Elexa Komputindo. Sitio A, Tamba H, 2001. Koperasi : Teori dan Praktik. Jakarta (ID) : Erlangga.

Situmorang JW. 2008. Peringkat Provinsi dalam Membangun Ekonomi Koperasi Analisis Berdasarkan Indeks PEKR. Jakarta (ID): Deputi Bidang Pengkajian Sumberdaya UMKM. . 2012. Keunggulan Komparatif Provinsi dalam Pembangunan 
Koperasi Studi dengan Metode $R C A$. Jurnal Pengkajian Koperasi dan UKM Vol.07/1-21/Okt

Sujianto AE. 2012. Variabel-Variabel yang Mempengaruhi Kinerja operasi Pondok Pesantren di Kabupaten Tulungagung. Jurnal Pendidikan dan Pembelajaran Volume 19 Nomor 2 Oktober 2012.

Sukirno, S. 2000. Makroekonomi Modern. Jakarta (ID): PT. Raja Grafindo Persada.

Tambunan. 2001. Perekonomian Indonesia : Teori dan Penemuan Empiris. Jakarta: Ghalia Indonesia.

Undang-Undang Nomor 12 Tahun 1967 Tentang Pokok-Pokok Perkoperasian. Jakarta (ID): Kementerian Koperasi dan Usaha Kecil dan Menengah. Pemerintah Republik Indonesia. 1992.

Undang-Undang Republik Indonesia Nomor 25 Tahun 1992 tentang Perkoperasian. Jakarta (ID): Kementerian Koperasi dan Usaha Kecil dan Menengah.

Susilo. 2004. Analisis Faktor Yang Mempengaruhi Keberhasil-an Usaha Koperasi Pegawai Negeri Di Kabupaten Karanganyar. Jurnal Bisnis dan Manajemen Vol.7/No.2. 